\title{
MEMBANGUN MASYARAKAT MADANI DENGAN MENINGKATKAN SUMBER DAYA MANUSIA DI DESA PABANGBON
}

\author{
Arien Heryansyah $^{1}$, Robi Maulana, Siti Nur Yasinta Rahma, Flora Handayani ${ }^{2}$ \\ arien@ft.uika-bogor.com \\ Dosen Fakultas Teknik ${ }^{1}$, Mahasiswa KKN Kelompok 59 Tahun $2018^{2}$
}

\begin{abstract}
ABSTRAK
KKN Tematik Terintegrasi adalah KKN yang orientasi program terfokus pada bidang tertentu sesuai dengan permasalahan kemasyarakatan dan arah kebijakan pembangunan yang diselenggarakan pemerintah pada wilayah tertentu (Kabupaten/ Kota). Kuliah Kerja Nyata bertujuan untuk mencapai ekselerasi dan efektivitas program pembangunan yang ditandai dengan semakin baiknya kualitas kehidupan masyarakat dan program program pembangunan. Program kelompok di Desa Pabangbon merupakan program yang lebih menekankan kepada tema pemberdayaan Sumber Daya Masyarakat. Program kerja kelompok 59 antara lain: Taman Baca, Mengajar SD, Mengajar PAUD, Perlombaan 17 Agustus antar SD, Perlombaan cerdas cermat antar SD, Penyuluhan Hukum perkawinan dan hukum tanah dalam aspek perdata dan pidana, Sosialisasi akte kelahiran terkait pendaftaran akte kelahiran servis efisien melalui adminduk online gratis akurat terintegrasi, Konsultasi hukum, Penyuluhan strategi pemasaran dan peningkatan SDM UMKM di pedesaan, Pengajaran dasar TIK di SD, Membuat Running text untuk masjid, Penyuluhan terkait urgensi cuci tangan bagi kesehatan, Senam sehat, Membuat tong sampah, Mengajar pengajian anak (surau), Mengajar diniyah, Pengajian akbar bulanan BKMT (Badan Kontak Majlis Ta'lim), Tabligh Akbar, Perlombaan 17 Agustus di desa, Upacara 17 Agustus di desa. Secara umum kegiatan KKN di Desa Pabangbon Kecamatan Leuwiliang Kabupaten Bogor berjalan dengan baik dan lancar. Pelaksanaan program kerja tersebut diharapkan dapat bermanfaat bagi seluruh pihak.
\end{abstract}

\section{Keyword: KKN, Pabangbon, Leuwiliang.}

\section{PENDAHULUAN}

\section{Latar Belakang}

KKN adalah suatu bentuk pendidikan dengan cara memberikan pengalaman belajar kepada mahasiswa untuk hidup ditengah-tengah masyarakat,secara terstruktur melalui beberapa tahap diantaranya persiapan, pembekalan, observasi sampai tahap evaluasi. Sebagaiman

pengertian dari KKN Tematik Terintegrasi adalah KKN yang orientasi program terfokus pada bidang tertentu sesuai dengan permasalahan kemasyarakatan dan arah kebijakan pembangunan yang diselengarakan pemerintah pada wilayah tertentu (Kabupaten/ Kota). Dengan demikian bahwa KKN Tematik Terintegrasi berbasis problem solving untuk memecahkan masalah dengan tema tertentu sehingga kegiatan mahasiswa terfokus untuk mengatasi masalah tertentu sehingga kegiatan mahasiswa terfokus untuk mengatasi masalah tertentu dan untuk 
mencapai target tertentu sesuai dengan permasalahan.

Pembekalan KKN diselengarakan oleh pihak LPPM pada tanggal 30 Juli 2018 di ruang rektorat lt 3 dan membekali mahasiswa dengan materi pemberdayaan masyarakat dan materi yang terkait dengan teknis kegiatan KKN. Melakukan koordinasi dengan Dosen Pembimbing Lapangan (DPL) KKN kelompok secara efektif. Mahasiswa KKN juga mengadakan pertemuan secara rutin membahas program kerja.

Ketika penerjunan ke lokasi KKN, para mahasiswa melakukan kegiatan observasi. Kegiatan ini dilakukan sebelum mahasiswa benar-benar terjun ke lokasi KKN. Kegiatan ini dilakukan untuk mengamati secara langsung terhadap situasi, kondisi, sarana, dan prasarana yang ada di lokasi KKN dalam hal ini desa guna mendukung proses kuliah kerja nyata di desa tersebut

\section{Kondisi Wilayah}

Desa Pabangbon merupakan salah satu desa yang terletak kecamatan Leuwiliang, Bogor. Sebagian besar wilayah Desa Pabangbon terdiri dari persawahan. Desa Pabangbon memiliki luas desa 1197 Ha. Batas wilayah Desa Pabangbon yaitu meliputi :

Batas Utara : Desa Sadeng Kolot

Batas Selatan : Desa Bantar Karet

Batas Barat : Desa Leuwisadeng

Batas Timur : Desa Karacak

Desa Pabangbon memiliki jumlah penduduk 1783 penduduk.

\section{Kondisi Mata Pencaharian}

Kondisi mata pencaharian warga Desa Pabangbon umumnya memiliki mata pencaharian sebagai petani dan pedagang kecil serta sebagian besar memilki industry rumahan seperti industry kolang kaling dan industry keripik pisang. Hal ini karna lokasi desa yang berada jauh dari pasar maka warga desa memanfaatkannya untuk berjualan, banyak lokasi yang strategis untuk berjualan seperti di tempat wisata Panorama Pabangbon dan Bukit Bintang namun jarang dari warga yang dapat berjualan disana karna perizinan untuk berjualan yang cukup rumit, hal ini menyebabkan warga hanya dapat berjualan didepan rumah masing-masing dan kurang dapat mengembangkan usahanya dan dengan memanfaatkan Sumber Daya Alam yang ada dapat lebih dikembangkan dan dikemas supaya dapat menjadi produk unggulan ekonomi desa dan mendatangkan income yang lebih baik serta dapat dibantu dengan adanya tempat wisata yang ada di desa agar dapat mengembangkan UMKM yang ada.

\section{Kondisi Kesehatan}

Sanitasi lingkungan yang cukup bersih karna ditanami oleh pepohonan yang membuat asri lingkungan sekitar, namun air tidak memadai. Pengelolaan sampah yang kurang baik, karna hanya di bakar dan dibuang ke jurang-jurang, hal ini membuat sampah menjadi berserakan dan tidak terlihat indah. Kondisi kesehatan warga desa Pabangbon hampir 85\% sangat amat sehat. Karna rutinitas yang dikerjakan oleh warga Pabangbon tidak terlalu berat seperti sector pariwisata, sector pertanian, sector rumahan dan lain-lain dan tidak ada penyakit menular yang membahayakan juga jarang ada warga yang terkena penyakit namun lingkungan yang lembab menyebabkan timbulnya jentik nyamuk. Sebelum bulan Desember 2017 ada penyemprotan fogging guna memberantas jentik nyamuk. Warga desa yang sakitnya tidak parah biasanya dapat berobat ke 
bidan desa, dan bidan desa setiap hari selasa rutin mengunjungi puskesmas pembantu yang berada dekat dengan kantor desa yang biasanya dikunjungi oleh LANSIA, orang tua yang memiliki balita dan ibu hamil guna memeriksa kehamilan. Dan apabila ada warga yang memiliki penyakit yang cukup parah seperti DBD akan dilarikan ke rumah sakit umum yang berada di daerah Leuwiliang.

\section{Kondisi Pendidikan}

Kondisi pendidikan yang ada di Desa Pabangbon. Pendidikan tertinggi yang dimiliki oleh warga desa Pabangbon adalah SMA dan sebagian kecil dapat mencapai tingkat pendidikan tinggi, hal ini terjadi karna masih maraknya pernikahan dini dan pernikahan siri yang terjadi di desa Pabangbon sehingga pendidikan bukan lagi sebagai hal utama yang harus dimiliki oleh setiap warga desa. Hal ini pun terjadi karna belum adanya fasilitas pendidikan yang memadai di desa Pabangbon. Fasilitas pendidikan yang ada didesa Pabangbon hanya ada 3 PAUD dan 5 SD sedangkan untuk SMP sederajat dan SMA sederajat belum ada didesa Pabangbon hal ini menyebabkan warga desa yang akan masuk kejenjang SMP dan SMA harus keluar desa Pabangbon untuk dapat bersekolah. Begitupun dengan guru-guru yang bertugas di setiap sekolah belum banyak yang meraih gelar sarjana dan mendapatkan sertifikasi hal ini menyebabkan kurangnya pendidikan yang ada disetiap sekolah. Sedangkan untuk pendidikan agama yang ada didesa Pabangbon sangatlah baik terbukti karena banyaknya diniah dan pengajian surau untuk anak dan banyaknya majlis ta'lim ada sekitar 17 majlis ta'lim yang berdiri di desa Pabangbon.

\section{METODE PELAKSANAAN}

Tahapan Pelaksanaan

\begin{tabular}{|c|l|c|c|c|c|}
\hline \multirow{2}{*}{ NO } & \multicolumn{1}{|c|}{ Kegiatan } & \multicolumn{3}{|c|}{ Minggu } \\
\hline & & $\mathbf{1}$ & $\mathbf{2}$ & $\mathbf{3}$ & $\mathbf{4}$ \\
\hline 1 & Taman Baca & & & & \\
\hline 2 & Mengajar SD & & & & \\
\hline 3 & Mengajar PAUD & & & \\
\hline 4 & Perlombaan 17 Agustus antar SD & & & \\
\hline 5 & Perlombaan cerdas cermat antar & & & \\
\hline 6 & $\begin{array}{l}\text { Penyuluhan Hukum perkawinan dan hukum tanah dalam } \\
\text { aspek perdata dan pidana }\end{array}$ & & & \\
\hline 7 & $\begin{array}{l}\text { Sosialisasi akte kelahiran terkait pendaftaran akte kelahiran } \\
\text { servis efisien melalui adminduk online gratis akurat } \\
\text { terintegrasi }\end{array}$ & & & \\
\hline 8 & Konsultasi hukum untuk masyarakat Pabangbon & & \\
\hline 9 & $\begin{array}{l}\text { Penyuluhan strategi pemasaran dan peningkatan SDM } \\
\text { UMKM di pedesaan }\end{array}$ & & & & \\
\hline 10 & Pengajaran dasar TIK di SD & & & \\
\hline
\end{tabular}




\begin{tabular}{|c|l|l|l|l|l|}
\hline 11 & Membuat Running text untuk masjid & & & \\
\hline 12 & Penyuluhan terkait urgensi cuci tangan bagi kesehatan & & & & \\
\hline 13 & Senam sehat & & & & \\
\hline 14 & Membuat tong sampah & & \\
\hline 15 & Mengajar pengajian anak (surau) & & \\
\hline 16 & Mengajar diniyah & & \\
\hline 17 & $\begin{array}{l}\text { Pengajian akbar bulanan BKMT (Badan Kontak Majlis } \\
\text { Ta'lim) }\end{array}$ & & & \\
\hline 18 & Tabligh Akbar & & & \\
\hline 19 & Perlombaan 17 Agustus di desa & & & \\
\hline 20 & Upacara 17 Agustus di desa & & & \\
\hline
\end{tabular}

\section{Metode Pengabdian}

Metode pengabdian yang digunakan dalam kegiatan ini adalah:

1. Pendekatan religius, yaitupendekatan yang menggunakan nilai-nilai agama sebagai basis kegiatan. Pendekatan ini sangat penting karna umumnya Masyarakat desa Pabangbon memiliki pemahaman Agama yang sangat baik (Rachmawati, 2010).

2. Pendekatan kekerabatan, artinya bahwa pembinaan yang dilakukan senantiasa dikaitkan dalam rangka membangun kekerabatanan tarjama'ah yang semakin memudar. Nurhayati (2005) menemukan bahwa faktor pendukung toleransi umat Islam dengan Hindu adalah adanya sistem kekerabatan.

3. Pendekatan berdasarkan karakter masyarakat, yakni pembinaan yang dilakukanakan disesuaikan dengan karakter masyarakat. Joyce dan Weil (1996) mengungkapkan bahwa model pendidikan yang relevan dengan perilaku sosial dan nilai adalah dengan banyak memberikan permainan peran. Hal ini dilakukan untuk memberi pengalaman riil kepada peserta didik tentang sesuatu yang dilakukan atau dirasakan oleh orang lain. Memang, dalam prakteknya, tidak seluruh aspek harus menggunakan permainan ini. Dalam beberapa hal, terdapat kegiatan-kegiatan yang hanya golongan tertentu untuk melakukannya. Sejalan dengan konsep Joyce dan Weil, cooperative learning yang digagas Slavin (2005) dapat digunakan untuk membangun kesadaran toleransi masyarakat. Hal ini karena penekanan dari konsep pendidikan ini adalah kerja sama yang merupakan urat nadi toleransi. Dengan demikian, model pendidikan yang akan dibangun menggunakan dua konsep utama yaitu role playing model dan cooperative learning model. 


\section{REALISASI PROGRAM}

Pelaksanaan KKN Tematik

Terintegrasi 2018 Universitas Ibn Khaldun Bogor dimulai pada tanggal 07 Agustus 2018 sampai 05 September 2018 yang pelaksanaannya dilakukan oleh peserta KKN dan masyarakat desa Pabangbon. Adapun program KKN dirinci sebagai berikut:

\section{Program kerja bidang pendidikan}

a. Taman Baca

Tujuan dan manfaat diadakannya program kerja ini adalah agar dapat meningkatkan minat baca masyarakat Desa Pabangbon. Kegiatan ini di tujukan untuk anak-anak di Desa Pabangbon Waktu pelaksanaan setiap hari senin sampai hari kamis dari jam 13.30-14-30 WIB yang dilakukan di posko KKN kelompok 59.

Hasil dari dilaksanakannya kegiatan ini adalah terealisasinya tujuan yang telah di rencanakan yaitu meningkatnya minat baca Anak-anak di Desa Pabangbon.

b. Mengajar di SD

Tujuan dan manfaat dilaksanakannya kegiatan ini adalah agar dapat membantu para guru yang ada di SD dalam mengajar para siswa dengan cara yang lebih menyenangkan dan bervariatif guna belajar untuk mengajar dan memahami karakteristik siswa SD. Kegiatan ini ditujukan untuk siswa kelas 4, 5 dan 6 waktu pelaksanaan setiap hari kamis dari jam 08.00-12.00 WIB yang dilakukan di SDN Pabangbon 01 mata pelajaran yang diajarkan adalah Bahasa
Inggris karena di sekolah tersebut tidak mempunyai guru bahasa Inggris yang kompeten dibidangnya.

Hasil dari dilaksanakannya kegiatan ini para siswa menjadi sangat antusias dan bersemangat dalam mengikuti pembelajaran sehingga pembelajaran dapat berjalan dengan efektif dan efisien.

c. Mengajar PAUD

Tujuan dan manfaat dilaksanakannya kegiatan ini adalah agar dapat membantu para guru yang ada di PAUD dalam mengajar para siswa dengan cara/ metode yang lebih menyenangkan dan bervariatif, agar dapat memahami karakteristik siswa PAUD. Kegiatan ini dilaksanakan setiap hari senin sampai hari jum'at dari jam $08.00-10.00$ WIB yang dilakukan di PAUD Nurul Iman.

Hasil dari dilaksanakannya kegiatan ini agar para siswa menjadi sangat antusias dan bersemangat dalam mengikuti pembelajaran sehingga dapat berjalan dengan efektif dan efisien.

d. Perlombaan 17 Agustus antar SD Tujuan dan manfaat dilaksanannya kegiatan ini adalah agar dapat memupuk rasa persaingan yang sehat dalam diri setiap siswa. Kegiatan ini dilaksanakan pada tanggal 17 Agustus 2018 jam 09.00 - 11.00 WIB yang dilaksanakan di Lapangan Pabangbon 2, kegiatan ini pun diikuti oleh lima SD sederajat yaitu: SDN Pabangbon 
01, SDN Pabangbon 02, SDN Sinar Karya Baru, MI Nangela, SDN Harapan Mulya dan terdiri dari dua mata lomba yaitu; lomba makan kerupuk dan lomba balap karung.

Hasil dari dilaksanakannya kegiatan ini agar para siswa menjadi terbiasa dengan persaingan yang sehat tanpa kecurangan dan sportifitas yang tinggi.

e. Perlombaan Cerdas Cermat antar SD

Tujuan dan manfaat dilaksanakannya kegiatan ini adalah agar dapat memupuk rasa persaingan yang sehat dan sportifitas yang tinggi dalam diri siswa. Kegiatan ini dilaksanakan pada 02 September 2018 jam 08.00-11.30 WIB yang dilaksanakan di Majlis Ta'lim Nurul Iman, kegiatan ini pun diikuti oleh 3 SD yaitu; SDN Pabangbon 01, SDN Pabangbon 02, SDN Sinar Karya Baru dan terdiri dari tiga mata lomba yaitu; Ceramah, Cerdas Cermat, dan Hifdzul Qur'an.

Hasil dari dilaksanakannya kegiatan ini para siswa menjadi terbiasa dengan persaingan yang sehat tanpa kecurangan dan sportifitas yang tinggi.

\section{Program Kerja Bidang Hukum}

a. Penyuluhan Hukum perkawinan dan hukum tanah dalam aspek perdata dan pidana

Tujuan dan manfaat dilaksanakannya kegiatan ini adalah untuk memberikan pemahaman yang mendalam tentang pentingnya hukum dalam kehidupan khususnya mengenai hukum perkawinan dan hukum tanah dalam aspek perdata maupun pidana yang mengacu pada Undang-Undang yang berlaku yaitu KUHPerdata, KUHPidana, dan UU No 1 Tahun 1974 Tentang Perkawinan. Kegiatan ini dilaksanakan pada 13 Agustus 2018 jam 09.00- 11.30 WIB yang dilaksanakan di Majlis Ta'lim Nurul Iman, kegiatan ini pun diikuti oleh jama'ah majlis ta'lim dan para masyarakat desa Pabangbon.

Hasil dari dilaksanakannya kegiatan ini masyarakat desa Pabangbon dapat memahami pentingnya hukum dalam kehidupan khususnya mengenai hukum perkawinan dan hukum tanah dalam aspek perdata dan aspek pidana sebagaimana undang-undang yang berlaku..

b. Sosialisasi akte kelahiran terkait pendaftaran akte kelahiran servis efisien melalui adminduk online gratis akurat terintegrasi

Tujuan dan manfaat dilaksanakannya kegiatan ini adalah untuk memberikan pemahaman yang mendalam tentang pentingnya akte kelahiran untuk pendataan kependudukan sebagaimana Undang-Undang Nomor 23 Tahun 2006 Tentang Administrasi kependudukan pasal 27 mewajibkan pendaftaran akte kelahiran dan mengarahkan mengenai pendaftaran akte kelahiran online gratis melalui website yang disediakan oleh Disdukcapil Kabupaten Bogor. 
Kegiatan ini dilaksanakan pada 10 Agustus 2018 jam 09.00- 11.30 WIB yang dilaksanakan di Majlis Ta'lim Nurul Iman, kegiatan ini pun diikuti oleh jama'ah majlis ta'lim dan para masyarakat desa Pabangbon.

Hasil dari dilaksanakannya kegiatan ini masyarakat desa Pabangbon dapat memahami pentingnya akte kelahiran untuk pendataan kependudukan dan dapat mendaftarkan akte kelahiran di Disdukcapil kabupaten Bogor ataupun secara online secara gratis dalam website http ://semangatbogorkab.go.id.

c. Konsultasi hukum untuk masyarakat desa Pabangbon

Tujuan dan manfaat dilaksanakannya kegiatan ini adalah memberikan wadah untuk masyarakat dalam menghadapi permasalahan hukum sehingga dapat memahami permasalahan hukum dan akibat hukumnya sebagaimana Undang-Undang yang berlaku. Kegiatan ini dilaksanakan di Posko KKN 59 setiap hari senin sampai dengan Minggu . Senin-Sabtu jam 10.0015.00 dan Minggu jam 08.0012.00. Kegiatan ini pun diikuti oleh warga Desa Pabangbon yang sangat antusias dalam berkonsultasi hukum.

Hasil dari dilaksanakannya kegiatan ini bisa menjadi konsultan hukum yang dapat membantu masyarakat desa Pabangbon menghadapi permasalahan hukum baik mengenai hukum perkawinan dan hukum tanah dalam aspek perdata maupun aspek pidana yang mengacu pada KUHPerdata, UU No 1 Tahun 1974 dan KUHPidana maupun pentingnya akte kelahiran sebagaimana Undang-Undang Nomor 23 Tahun 2006.

\section{Program kerja bidang ekonomi}

Penyuluhan strategi pemasaran dan peningkatan SDM UMKM di pedesaan

Tujuan dan manfaat dilaksanakannya kegiatan ini adalah agar masyarakat desa Pabangbon memiliki pemahaman yang mendalam mengenai strategi pemasaran yang baik dikarenakan sebagian besar warga desa Pabangbon merupakan memiliki wirausaha seperti berdagang maupun usaha rumahan. Kegiatan ini dilaksanakan pada 31 Agustus 2018 jam 09.00-11.30 WIB yang dilaksanakan di Majlis Ta'lim Nurul Iman dan dihadiri oleh para jama'ah Majlis Ta'lim Nurul Iman serta warga desa Pabangbon.

Hasil dari dilaksanakannya kegiatan ini adalah masyarakat desa Pabangbon memiliki pemahaman yang mendalam mengenai strategi pemasaran yang baik dan bagaimana cara mengembangkan usaha yang telah dijalani.

\section{Program kerja Bidang teknik}

a. Pengajaran dasar TIK di SD

Tujuan dan
dilaksanakannya megiatan ini
adalah agar anak-anak desa
Pabangbon dapat memiliki
pemahaman tentang dasar
komputer secara mendalam
dikarnakan tidak ada fasilitas
yang disediakan oleh sekolah
berupa komputer karna itulah


kami membuat program ini. Kegiatan ini dilaksanakan pada 25 Agustus 2018 jam 08.00- 09.30 WIB yang dilaksanakan di SDN Pabangbon 02 sasaran kegiatan ini adalah kelas 6 SD.

Hasil dari dilaksanakannya kegiatan ini para siswa dapat memahami tentang dasar TIK dan langsung mempraktekannya mengunakan leptop yang telah disediakan oleh anggota KKN.

b. Membuat Running text untuk masjid

Tujuan dan manfaat dilaksanakannya kegiatan ini adalah untuk pemberian waqaf kepada desa Pabangbon, waqaf ini ditempatkan di masjid Jami' Nurul Iman dan diberikan pada acara tabligh akbar dan perpisahan anggota KKN yang dilaksanakan pada 02 September 2018.

\section{Program kerja bidang kesehatan}

a. Penyuluhan terkait urgensi cuci tangan bagi kesehatan

Tujuan dan manfaat dilaksanakannya kegiatan ini adalah agar anak-anak memiliki pemahaman dan pengetahuan yang mendalam mengenai urgensi cuci tangan bagi kesehatan dan dapat mengetahui cara mencuci tangan yang baik dan benar. Kegiatan ini dilaksanakan pada 20 Agustus 2018 jam 08.00- 10.00 WIB yang dilaksanakan di SDN Pabangbon 02 sasaran kegiatan ini adalah kelas 1, 2, dan 3 SD.

Hasil dari dilaksanakannya kegiatan ini para siswa dapat memahami urgensi cuci tangan bagi kesehatan dan mengetahui bagaimana cara mencuci tangan yang baik dan benar dengan langsung diadakannya praktek mencuci tangan mengunakan media menyanyi.

b. Senam sehat

Tujuan dan manfaat dilaksanakannya kegiatan ini adalah untuk memfasilitasi masyarakat desa Pabangbon agar bisa melakukan olahraga berupa senam sehat. Kegiatan ini dilaksanakan pada 19 Agustus 2018 jam 08.00- 09.30 WIB yang dilaksanakan di Lapangan Pabangbon 02 yang dihadiri oleh masyarakat desa khususnya ibuibu dan anak-anak diwilayah setempat.

Hasil dari dilaksanakannya kegiatan ini masyarakat desa dapat membiasakan hidup sehat dengan olahraga berupa senam sehat yang telah dilaksanakan anggota $\mathrm{KKN}$ dan antusias warga yang sangat baik.

c. Membuat tong sampah

Tujuan dan manfaat dilaksanakannya kegiatan ini adalah untuk pemberian waqaf kepada desa Pabangbon, waqaf ini ditempatkan di 6 titik pusat seperti kantor desa, masjid Jami' Nurul Iman, PAUD Nurul Iman, SDN Pabangbon 01, SDN Pabangbon 02, dan SDN Sinar Karya Baru, yang diberikan pada acara tabligh akbar dan perpisahan anggota KKN yang dilaksanakan pada 02 September 2018.

Hasil dari dilaksanakannya kegiatan ini untuk memfasilitasi agar warga desa Pabangbon tidak 
membuang sampah sembarangan dan agar lingkungan desa Pabangbon menjadi lebih bersih dan masyarakat pun akan menjadi lebih sehat karna dapat meminimalisir sampah yang berserakan.

\section{Program kerja bidang agama}

a. Mengajar pengajian anak (surau) Tujuan dan manfaat dilaksanakannya kegiatan ini adalah agar dapat membantu guru dalam mengajar para siswa mengaji Al-Qur'an dengan Murotal maupun Mujawaj dan juga mengajarkan para siswa untuk belajar berceramah (Muhadhoroh). Kegiatan ini dilaksanakan setiap hari senin sampai hari jum'at dari jam 18.30- 19.30 WIB yang dilakukan di surau desa Pabangbon 2.

Hasil dari dilaksanakannya kegiatan ini anak-anak yang ada di desa Pabangbon khususnya di Pabangon 2 dapat belajar mengaji dengan cara Murotal dan Mujawaj dan dapat belajar teknik berceramah (Muhadhoroh) dengan baik dan benar.

b. Mengajar diniyah

Tujuan dan manfaat dilaksanakannya kegiatan ini adalah agar dapat membantu guru dalam mengajarkan pelajaran agama seperti Bahasa Arab, Sejarah Kebudayaan Islam, Hadist, Al-Qur'an, Akidah Akhlak dan Fiqh. Kegiatan ini dilaksanakan setiap hari senin sampai kamis jam 13.00- 14.00 WIB yang dilakukan di Majlis Ta'lim Nurul Iman.
Hasil dari dilaksanakannya kegiatan ini adalah anak-anak dapat menjadi lebih semangat dalam belajar karna mengunakan metode yang bervariatif sehingga pembelaaran menjadi lebih efektif dan efisien.

c. Pengajian akbar bulanan BKMT (Badan Kontak Majlis Ta'lim) Tujuan dan manfaat dilaksanakannya kegiatan ini adalah agar dapat menjalin silaturahmi dengan jama'ah dari 13 Majlis Ta'lim yang ada didesa Pabangbon, juga mengembangkan potensi sebagai Da'i di masyarakat. Kegiatan ini dilaksanakan pada 26 Agustus 2018 jam 08.00- 11.30 WIB yang dilaksanakan dibalai desa Pabangbon.

Hasil dari dilaksanakannya kegiatan ini adalah membanggun masyarakat desa Pabangbon yang agamis, harmonis dan berakhlak mulia.

d. Tabligh Akbar

Tujuan dan manfaat dilaksanakannya kegiatan ini adalah sebagai wadah bagi mahasiswa untuk mengembangan potensi yang dimiliki dan mengamalkannya dimasyarakat dan merupakan acara perpisahan dari kelompok KKN 59 Univeritas Ibn Khaldun juga sebagai acara pemberian waqaf. Kegiatan ini dilaksanakan pada 02 September 2018 jam 19.30- 23.00 WIB yang dilaksanakan dimasjid Jami' Nurul Iman yang dihadiri masyarakat desa Pabangbon.

Hasil dari diadakannya kegiatan ini adalah untuk membangun 
silaturahim dan berpamitan antara Anggota KKN dengan warga desa Pabangbon.

\section{Kegiatan Desa}

a. Perlombaan 17 Agustus di desa Tujuan dan manfaat kegiatan ini adalah untuk memeriahkan hari kemerdekaan Indonesia yang ke73. Kegiatan ini dilaksanakan pada 19 Agustus 2018 jam 09.3011.30 WIB yang dilaksanakan di Lapangan desa Pabangbon 02 yang dihadiri oleh masyarakat desa Pabangbon khususnya ibuibu yang ada diwilayah setempat. Dan antusias warga desa Pabangbon yang sangat baik.

b. Upacara 17 Agustus di desa Tujuan dan manfaat kegiatan ini adalah agar belajar menjadi petugas upacara yang baik dan ikut berpartisipas dalam upacara 17 Agustus di desa Pabangbon. Kegiatan ini dilaksanakan pada 17 Agustus 2018 jam 08.00- 09.00 WIB yang dilaksanakan di Lapangan Desa Pabangbon 2.

\section{KESIMPULAN DAN DAMPAK BAGI MASYARAKAT}

Kegiatan KKN dengan sasaran masyarakat desa Pabangbon sebagai bagian dari masyarakat secara umum berjalan dengan lancar sesuai dengan apa yang telah direncanakan dalam matrik program kerja KKN.

Adapun kesimpulan dari pelaksanaan program kerja KKN masyarakat:

1. Program kerja KKN dapat terlaksana dengan baik dan lancar meski ada beberapa tambahan dan perubahan serta waktu pelaksanaan yang kurang sesuai dengan yang direncanakan.

2. Program ini dapat berjalan dengan baik berkat dukungan dan kerja sama antar warga dan pihak masyarakat yang sangat membantu dan mendukung.

Dengan demikian, hasil kesimpulan di atas menunjukan bahwa secara garis besar program KKN dapat dikatakan sukses dan lancar meskipun waktunya lebih maju atau lebih mundur.

\section{SARAN}

Berdasarkan hasil pelaksanaan program KKN yang dilaksanakan sejak 7 Agustus sampai 5 September 2018 terdapat nenerapa saran yang sekiranya membangun bagi semua pihak, antara lain:

\section{Kepada Desa Pabangbon}

a. Program-program yang telah dilaksanakan oleh mahasiswa sebaikmya ada pengembangan atau tindak lanjut untuk peningkatan selanjutnya.

b. Hubungan yang sudah terjalin antara pihak universitas dengan pihak masyarakat hendaknya dapat lebih ditingkatkan dan dapat memberikan umpan balik satu sama lainnya.

\section{REFERENSI}

Bahari. (2010). Toleransi Beragama Mahasiswa (Studi tentang Pengaruh Kepribadian, Keterlibatan Organisasi, Hasil Belajar Pendidikan Agama, dan Lingkungan Pendidikan terhadap Toleransi Mahasiswa Berbeda Agama pada 7 
Perguruan Tinggi Umum Negeri. Jakarta: Kementerian Agama RI Badan Litbang dan Diklat Puslitbang Kehidupan Keagamaan.

Gall, M. G. (2003). Educational Research an Introduction. Boston: Pearson Education, Inc.

Joyce, B. d. (1996). Models of Teaching. Boston: Allyn and Bacon.

Kusumadewi, L. (1999). Sikap dan Toleransi Beragama di Kalangan Mahasiswa: Studi di Tiga Perguruan Tinggi di Jakarta. Skripsi. Depok: FISIP UI.

Peneliti, T. (2006). Laporan Hasil Survei Pengetahuan, Sikap dan Perilaku Stakeholders terhadap Organisasi Masyarakat Sipil. Jakarta: LP3ES dan YAPPIKA.
Penyusun, T. (2008). Toleransi dalam Pasungan: Pandangan Generasi Muda terhadap Masalah Kebangsaan, Pluralitas dan Kepemimpinan Nasional. Jakarta: SETARA Institute.

Rachmawati, A. (2006). Toleransi Antar Umat Islam dan Katolik: Studi Kasus di Dukuh Kasaran, Desa Pasungan, Kecamatan Ceper, Kabupaten Klaten. Skripsi. Semarang: IAIN Walisongo.

Slavin, R. (2005). Cooperative learning: theory, research and practice. London: Allyn and Bacon.

Simanjuntak, PNH.(1999). Pokok-Pokok Hukum perdata Indonesia. Jakarta : Djambatan.

Talib, A. G. (2012). Socio-religious tolerance: exploring the Malaysian experience. Global Journal of Human Social Science.12(8).49-54. 